\title{
Workshop Problémy právního postavení menšin v historii a konference Problémy vymezení pojmu tzv. „starých a nových menšin'،
}

Ve dnech 26. a 27. února 2019 se na Právnické fakultě UK uskutečnily dvě události, které na sebe svou tematickou blízkostí cíleně navazovaly. Toto spojení vytvořilo působivou platformu pro sdílení poznatků a odbornou diskuzi v oblasti zkoumání problematiky menšin.

První akce s názvem „Problémy právního postavení menšin v historii“ byla organizována v rámci projektu NAKI II DG18P02OVV064 Právní, historické a společenskovědní aspekty nových a tradičních menšin v České republice.

Její první blok zahájil svým vystoupením prof. JUDr. Jan Kuklík, DrSc., děkan Právnické fakulty Univerzity Karlovy. Zajímavě přiblížil nejen historický vývoj ochrany menšin v mezinárodním kontextu, ale také některé specifické problémy, které tuto problematiku provázely - např̀. náročnost definování menšiny a její různé chápání. Prof. Kuklík také shrnul, co bylo v této oblasti doposud probádáno, a naznačil možný směr dalšího výzkumu. Následoval příspěvek Dr. Grzegorza Gąsiora (Uniwersytet Warszawski), který pojednával o stanovisku československých úřadů vůči stížnostem polské menšiny na ekonomický útisk v letech 1920-1938. Blok byl zakončen regionálně orientovaným vystoupením PhDr. Miroslavy Jouzové, Ph.D. z Kolína, které postihlo nejen situaci židovských uprchlíků z Haliče, ale také jejich souvěrců z Kolínska a Kutnohorska, kteří byli v letech 1914-1918 postaveni před složitý úkol uprchlíkům v rámci svých omezených možností podat pomocnou ruku.

Další regionální sondou do historie v podobě příspěvku Mgr. Lubomíra Hlavienky, Ph.D. ze Slezské univerzity v Opavě navázal druhý blok workshopu. Dr. Hlavienka seznámil přítomné se svou analýzou situace na území okresů Bruntál, Rýmařov a Krnov v letech 1948-1960 z hlediska složení národnostních menšin. Následoval příspěvek Mgr. Lukasze Grzesiczaka z Opavy, který naopak postihoval recentní vnímání problémů polské menšiny v České republice některými vybranými polskými periodiky. K přiblížení určitých aspektů historického vývoje problematiky menšin se opět vrátilo vystoupení doc. PhDr. Jana Němečka, DrSc. (HIU AV ČR, Praha). Ve svém př́íspěvku se doc. Němeček věnoval národnostnímu statutu, který měl řešit komplikovanou otázku menšin v Československu ve druhé polovině 30. let, a který zůstal, především z mezinárodněpolitických důvodů, ve stadiu návrhu. Do současnosti a dokonce snad i do budoucího vývoje bylo orientováno poslední vystoupení, ve kterém předestřel vybrané otázky problematiky menšin v dnešním globalizovaném světě poslední referující druhého bloku PhDr. Salim Murad, Ph.D. (HTF UK). Nastínil komplikované problémy, před které bude pravděpodobně Česká republika v nejbližší době v rámci světové „globální vesnice“ postavena. 
Rovněž čas posledního bloku workshopu byl, podobně jako první dva, bezezbytku zaplněn v mnoha ohledech podnětnými příspěvky. Otevřel jej příspěvek prof. PhDr. Dušana Hanáka, Ph.D. z Opavy, pojednávající o ukrajinské reemigraci z Československa do SSSR ve 20. a 30. letech 20. století. Prof. Hanák v něm nastínil řadu paradoxů provázejících toto specifické téma. Následoval neméně zajímavý referát dr. Thomase Oellermanna, Ph.D. (Friedrich-Ebert-Stiftung v České republice), který komplexním způsobem zhodnotil působení politika Wenzela Jaksche ve vztahu k německé menšině, především v komplikovaných předválečných a válečných letech. Poté zazněl příspěvek PhDr. Heleny Noskové, CSc. (ÚSD AV, Praha) orientovaný na národnostní menšiny v okrese Tachov po roce 1945. S některými aspekty právního postavení židovského obyvatelstva v letech 1945-1948 seznámil přítomné PhDr. Petr Bednařík, Ph.D. (ÚSD AV, Praha). Příslovečnou „třešničkou na dortu“, která celý den věnovaný workshopu „Problémy právního postavení menšin v historii“ zakončila, byl pak referát prof. JUDr. Mahuleny Hofmannové, CSc. (PF UK, UNI Lucemburk). Prof. Hofmannová ve svém příspěvku osvětlila historii monitoringu situace menšin v ČR výborem Jazykové charty, prriblížila, jak monitoring prakticky funguje a navíc položila řadu důležitých otázek týkajících se jeho významu.

Druhá akce s názvem „Problémy vymezení pojmu tzv. ,starých a nových“ menšin“ byla uspořádána v rámci projektu Progres Q05: Právní a společenské aspekty postavení menšin. První dva bloky představovaly společně sekci ,vymezení pojmu menšina v minulosti a dnes".

Podobně jako předešlého dne se v úvodu ujal slova prof. JUDr. Jan Kuklík, DrSc. Na prof. Kuklíka navázal jeho kolega z Právnické fakulty UK JUDr. PhDr. René Petráš, Ph.D., který se problematice menšin věnuje cíleně a dlouhodobě. Ve svém vystoupení se dr. Petráš soustředil na vymezení menšin v české historii. Upozornil například na historicky odlišné chápání menšin jako potenciálně problémového prvku, nikoli jako skupiny s určitým oprávněním. Další referát na téma obyvatel Hlučínska jako menšiny v Československu v letech 1920-1993, přednesl Mgr. Ondřej Kolář, Ph.D. (Slezské zemské muzeum v Opavě). Věnoval se především složitým jazykovým a národnostním otázkám ve zkoumané oblasti. První blok uzavíral př́ispěvek doc. PhDr. Blanky Soukupové, CSc. z Fakulty humanitních studií UK. Jak už předeslal název příspěvku, doc. Soukupová seznámila prítomné s výsledky svého výzkumu problematiky pojetí Židů v moderní době a pokusila se vymezit, zda a do jaké míry se jedná o menšinu náboženskou, národnostní nebo národ, a to $z$ perspektivy samotných Židů i většinové společnosti.

V rámci druhého bloku první sekce se přítomným dostalo pár „menšinových ochutnávek“ z oblasti Mad’arska, Slovenska a Podkarpatské Rusi. Prof. Dr. Iván Halász, Ph.D. (MAV SVC Budapest) přiblížil svým příspěvkem pokusy o uznání nových menšin v Mad'arsku za posledních dvacet let. Posluchači nejen, že byli pregnantně seznámeni se samotným procesem uznávání menšin a jejich složením v předmětném období v Mad'arsku, ale nebyli ochuzeni ani o různé zajímavosti, např́klad v podobě pokusu o uznání hunské menšiny. V podobném duchu navázal doc. Laszlo Szarka, CSc. (UJS Komárno; Budapest) se svým vystoupením na téma praobyvatelské koncepce v meziválečném diskurzu na Slovensku a Podkarpatské Rusi. Doc. Szarka si primárně kladl klíčovou otázku, zda jsou tyto menšiny autochtonní?

Druhou sekci s názvem „nové pojetí menšin“ zahájila svým pozoruhodným referátem Mgr. Veronika Vítková z Kanceláře veřejného ochránce práv. Její velmi aktuální prríspěvek 
byl zaměřen na možnost vznímání osob se zdravotním postižením jako nové menšiny. Další „novou“ menšinu hodnou pozornosti - sexuální - představil doc. JUDr. Martin Štefko, Ph.D. z Právnické fakulty UK pohledem svého oboru, kterým je pracovní právo a právo sociálního zabezpečení. Na doc. Štefka tematicky navázal prof. JUDr. Richard Král, LL.M., Ph.D., DSc. rovněž z Právnické fakulty UK. Věnoval se též sexuálním menšinám, tentokrát prostřednictvím práva na volný pohyb unijních občanů, konkrétně se zajímavě zaměřil na stěžejní rozhodnutí Soudního dvora EU ve věci Coman. Sekci uzavřel svým jiskrným př́spěvkem na téma stereotypů a nových menšin kolega dvou předchozích řečníků z Právnické fakulty UK doc. Dr. iur. Mag. phil. Harald Scheu, Ph.D. Upozornil např́klad na náročnost samotného vymezení takových stereotypů a precizním způsobem předestřel problém potírání stereotypů v kontrapozici s náklady takového počínání.

Stranou pozornosti nezůstaly ani menšiny spojené s náboženskými otázkami, kterým byl vyhrazen prostor v poslední sekci označené příznačně ,náboženské menšiny“, a také ona, stejně jako obě předcházející, dostála dozajista svému označení.

Tato sekce byla velmi vhodně zahájena příspěvkem pojednávajícím o samotném vymezení pojmu náboženské menšiny, který působivě představila PhDr. ThDr. Noemi Bravená, Ph.D. z Husitské teologické fakulty UK. Na ni navázala její kolegyně ze stejné fakulty PhDr. Monika Nová, Ph.D., která seznámila přítomné se situací mongolské menšiny žijící v ČR a naznačila její další možné perspektivy. Následoval velmi komplexní př́íspěvek prof. PhDr. Luboše Kropáčka, CSc. (HTF UK) postihující integraci muslimských migrantů vnímanou křest’anskou optikou. Současný evropský pohled na mimořádně komplikovanou africkou migraci přidala doc. ThDr. Kamila Veverková, Th.D. (HTF UK). Třetí sekce pak byla zakončena zajímavým referátem ThDr. Pavly Damohorské, Th.D. (HTF UK), který zaujal nejen obsahem, ale již jen samotným názvem: „A cizinci nebudeš škodit, ani ho utlačovat“. Stát Izrael a současná migrační otázka - nová eritrejská menšina?

Oba konferenční dny byly vyplněny zajímavým programem. Ovšem bylo by jistě opomenutím na tomto místě, kromě bohatého a inspirativního obsahu, nevyzvednout také četné diskuze vedené nejen v rámci programu, ale též během přestávek.

Obě události představily a snad také vnesly světlo do řady různorodých otázek souvisejících s problematikou menšin a jejich vývojem nejen v minulosti, ale také v budoucích perspektivách. Právě ona různorodost v podobě spojení odborníků zkoumajících menšinovou problematiku z mnoha aspektů svých konkrétních oborů, byla více než příznačná, nebot' jsou to právě menšiny, které činí každou společnost rozmanitou. Obě akce přinesly rovněž mnoho neotřelých pohledů a vyvolaly nové otázky, které, doufejme, povedou v budoucnu k další úspěšné vědecké práci v této oblasti.

doi: 10.14712/2464689X.2019.22

Tereza Blažková 